\title{
EARLY CHARTIST ORGANIZATION AND THE CONVENTION OF $1839^{*}$
}

With the imprisonment of many activists throughout the year, ${ }^{1}$ the rejection of the first National Petition in July, the dissolution of the Convention ${ }^{2}$ in September, and the catastrophe of the ill-fated Newport Rising in November, early Chartism ended in failure in the second half of 1839 . One of the most common reasons given in the literature for the failure has been the lack of internal cohesion in the movement, usually illustrated by reference to the political conflicts between physical- and moral-force groups. Despite the analytical inadequacy of such generic terms it is indisputable that Chartism was deficient in natural unity. It was a coalition of many different radical associations and personalities with a multiplicity of varied experiences, traditions and beliefs. As a consequence, the early Chartist movement only made progress by adopting certain symbols of unification: the National Petition and Rent, and a commitment to a National Convention. These symbols then became specific goals of Chartism. However, little consideration has previously been given to asking whether Chartism was an efficient instrument in itself for achieving these objectives, or if the organization of the Convention undermined the political credibility of the movement. This article attempts to illustrate Chartism's need for organization and leadership from the Convention, and suggests that inefficient organi-

* I should like to thank Professor Asa Briggs, Mr D. M. Vincent and other members of the Confraternitas Historica at Sidney Sussex College, Cambridge, for commenting on earlier drafts of this article.

1 A Return from each Gaol and House of Correction in the United Kingdom from January 1, 1839 to June 1, 1840, stating: (1) The Name of every Person confined for Charges for Printing and Publishing Seditious or Blasphemous Libel, or for attending any Seditious Meetings, or for any offence of a Political Nature; the Nature of the Charge; the Term of Sentence suffered, (2) The Treatment before and after conviction, [...] (4) Comparative Treatment of Persons Confined for Misdemeanour before and after Conviction or Sentence [Parliamentary Papers: Accounts and Papers, 1840, XXXVIII].

${ }^{2}$ Officially titled the General Convention of the Industrious Classes, but known generally as the National Convention, or simply the Convention. 
zation was an important cause of the relative failure to achieve its immediate objectives, and for the progressive abdication of leadership by the Convention.

Chartism was born in the summer of 1838 . For the remainder of that year a succession of internal political teething problems arose, which made it necessary that the convention should provide good leadership and organization if the movement was to achieve any lasting success. The six months which elapsed between the first Chartist meeting at Birmingham in August 1838 and the opening of the Convention in February 1839 saw considerable in-fighting take place amongst the disparate forces which comprised the early Chartist movement. Chartism was a coalescence of different traditions, ideas and socioeconomic forces, and the leaders of the principal participant organizations, the London Working Men's Association (LWMA), the Birmingham Political Union (BPU) and the Scottish radicals, and the strange amalgam of militants which included Feargus $\mathrm{O}^{\prime}$ Connor, ${ }^{\mathbf{1}}$ the anti-PoorLaw men, and the London Democratic Association (LDA), were continually jockeying for position throughout this period.

One of the first conflicts arose between the BPU and the LWMA over the relationship between the National Petition and the People's Charter in the new movement. Both had been independently presented to the great radical meeting in Glasgow, organized by local radicals and trade unionists with the encouragement of the BPU, on 21 May 1838, and it has generally been assumed that the National Petition was always a petition for the Charter. However, this was not the case. The Petition was drafted independently of the Charter, ${ }^{2}$ and differed from it in a number of respects, ${ }^{3}$ the most important being that the Petition had only five points; it excluded all reference to equal electoral districts. ${ }^{4}$ The reason for this omission will become apparent later, but the independence of the Petition and Charter meant that before they could become twin symbols of a single movement negotiations had to take place between the LWMA and the BPU. These negotiations took place quite soon after the Glasgow meeting, and it was only as a result that

1 A former Irish MP, and owner of the Northern Star. Delegate to the Convention for the West Riding of Yorkshire and Bristol.

${ }^{2}$ By R. K. Douglas.

3 The Charter was drafted as a bill for parliament, whereas the petition was a rather verbose document full of Thomas Attwood's currency notions.

4 Gammage and subsequent historians believed that equal electoral districts were a part of universal suffrage. Cf. R. G. Gammage, History of the Chartist Movement, 2nd ed. (London, 1894), p. 90. 
the LWMA "agreed to make their [BPU's] National Petition the first petition for the Charter". ${ }^{1}$ The following extract from a letter by Henry Vincent the LWMA representative, dated 13 June 1838, indicates how delicate the situation was:

"Citizen and Brother - Here I am in Birmingham - and a pretty town it is. We have been well received by the leading men of the Union - and we have decided, after mature discussion, not to have a great public meeting for a fere weeks (the particulars of which I will hereafter explain to your satisfaction) - The Council meet tomorrow evening Tuesday, in the Public Hall, at which meeting members will attend, - Myself and Murphy are to address the meeting - They will adopt our Charter! - They may not agree with us in detail as you yourself do not - but that is nothing. The best possible feeling prevails, and there appears to be no jealousy. In fact, everything will be settled, not only to the gratification of our little, paltry, individual vanities, but to the success of our great and glorious cause." 2

Although the successful completion of these negotiations resolved one potential conflict they merely increased suspicion elsewhere. Writing after the collapse of the Convention, Matthew Fletcher, the delegate for Oldham, suggested that the alliance between the LWMA and the BPU was designed to end the agitation against the New Poor Law. Moreover, some months earlier The Times had made similar allegations:

"It is very strongly suspected that the Whig Ministers vere the actual founders of this Chartist agitation, and that many of the individuals now forming the National Convention were originally employed by them and paid out of the public purse (secret service, of course) to agitate for the Charter. Wise and wary politicians, who know something of the party, even the people's friend, Mr. Oastler, is of this opinion. They knew very well that the respectable portion of the community would be with them against granting any such preposterous claims, but it was an excellent trick to divert the people's attention from unanimously demanding a repeal of the New Poor Law Bill, which they would have done, but for this precious specimen of Whig cunning."3

1 William Lovett, The Life and Struggles of William Lovett in his Pursuit of Bread, Knowledge and Freedom (new ed., London, 1967), pp. 142-43.

2 The collected papers of Henry Vincent at Transport House, London, reference 1/1/6. See also R. F. Webb, "Birmingham and the Chartist Movement" (unpublished Ph.D. thesis, Birmingham University, 1926), p. 21.

${ }^{3}$ The Times, 21 May 1839. 
The circulation of such suspicions may well have been an important causal factor of the hostile relations between the North, and Birmingham and London, which existed, with particular intensity, in the latter part of 1838. Feargus O'Connor took advantage of this to weaken the position of the BPU leadership both in Birmingham and nationally. After some leading members of the BPU had accused O'Connor of violent and intemperate behaviour, he arrived unannounced and uninvited at the weekly meeting of the Union on the 13 November 1838 to defend himself. O'Connor handled affairs so well that the BPU divided against itself and caused acute embarrassment to the leadership. ${ }^{1}$ O'Connor succeeded in driving a further wedge ${ }^{2}$ between the middle-class leadership and the working-class rank-and-file, and this probably contributed to the ease with which Birmingham Chartism recovered after its middle-class delegates resigned en bloc in April $1839 .^{3}$ Moreover, O'Connor gave full coverage in the Northern Star to what he portrayed as his defence against unjustified and unnecessary criticism. Consequently the Manchester Political Union published an address to the working classes in Birmingham attacking moderates in general and the BPU leadership in particular.

"Beware working-men; do your own work; let not rich merchants and manufacturers lead you into the O'Connell snare. Without your aid they would become contemptible. Take your affairs into your own hand. We have no rich men leading or driving us but, in the true democratic spirit manage our own affairs. We will have no such dictators holding over us the threat of disunion if we rebel against their particular crotchets and mandates. They, in conjunction with the Working men's Association in London, and the Scotch philosophical radicals, shrink at the storm they have created, but we of the North will brave it out."4

This address was commended to universal reading by the Star and, therefore, further exacerbated the existing conflicts within Chartism. ${ }^{5}$

In London the LDA and the LWMA differed over the question of co-operation with non-working-class parliamentary radicals, or, as

${ }^{1}$ M. Hovell, The Chartist Movement, 3rd ed. (Manchester, 1970), pp. 112-13.

"Asa Briggs, "Social Structure and Politics in Birmingham and L.yons", in: British Journal of Sociology, I (1950), pp. 67-80.

3 In fact, even before O'Connor arrived in Birmingham, a local working man complained that "he had learned that to ensure the success of a motion in the Council, it was necessary that it should proceed from some wealthy and influential individual of that body - and not from a mere working man like himself". Northern Star, 17 November 1838.

Ibid., 22 December 1838.

Ibid. 
Harney ${ }^{1}$ preferred to describe them, "Malthusian Sham-radicals". 2 Despite attempts by Hartwell ${ }^{3}$ and Vincent, ${ }^{4}$ early in 1839 , to patch-up the differences there remained a fundamental difference in the political style of the two organizations. The LDA was shaped by Harney to become the "Jacobin"-like watchdog of the Convention and representative of the poorest elements in London, whereas the LWMA remained an influential and elitist body of intelligent artisans, which adopted a relatively moderate approach to politics. The dichotomy between moral- and physical-force Chartism is clearly illustrated by the differences between the two organizations and their two most well-known members, William Lovett ${ }^{5}$ and George Julian Harney.

The LWMA was indirectly involved in another metropolitan dispute in 1838, this time between two Chartist newspapers, Bronterre $\mathrm{O}^{\prime}$ Brien's ${ }^{6}$ Operative and the Charter. Unfortunately, "the Charter, an organ of the London Working Men's Association, [...] took up a hostile attitude to O'Brien's paper largely because of the Operative's militancy"7 and earlier, local, political disputes. The Operative naturally reciprocated, and prompted the Northern Star to adopt an unusually conciliatory attitude.

"There is only one thing in this number of the Operative with which we are disposed to find fault, and that is, in the address of the Committee, the depracatory and somewhat angry notice of the forthcoming Charter, which promises to be another paper for the people. We regret that this style of speaking should have been adopted by the Operative. [...] A good cause can never have too many champions."8

However, the harm had been done, and the possibility of merging the two papers, which would have been the sensible thing to do, ${ }^{9}$ did not materialize. Consequently, within six months the Operative ceased to appear, and less than a year later the Charter had to amalgamate with the Statesman and Weekly True Sun to survive.

In Scotland conflict between different wings of the movement arose

1 Delegate to the Convention for Derby, Northumberland and Norwich.

2 A. R. Schoyen, The Chartist Challenge (London, 1958), p. 19.

3 Delegate to the Convention for London, except Marylebone, and Stockport.

4 Delegate to the Convention for Hull, Cheltenham and Bristol.

5 Secretary of the LWMA and the Convention, and one of the delegates for London.

- Delegate to the Convention for London, except Marylebone, Leigh, Bristol, Norwich, Newport (Isle of Wight), and Stockport.

$?$ A. Plummer, Bronterre (London, 1971), p. 88.

- Northern Star, 10 November 1838.

A. Plummer, op. cit., p. 88. 
over the "Calton Hill Resolutions". An Edinburgh delegate conference met on 5 December 1838 and passed a series of resolutions disavowing physical force in the hope that they would influence the deliberations of the Convention. This prompted O'Connor and John Taylor ${ }^{1}$ to launch a successful counter-offensive against the resolutions (Harney, writing from London, declared that the resolutions were framed "to create disunion in the ranks of democracy"2) so as to consolidate the position of the physical-force Chartists before the opening of the Convention.

However, by this time, rank-and-file Chartists throughout the country were becoming anxious that the petty squabbling among their leaders should cease. Lovett thought that "the meeting of the Convention was fast approaching, and so strong was the hope that reposed in that meeting by the Chartist body, that the great majority of them manifested the strongest desire to sacrifice their particular feelings and convictions for the sake of union". ${ }^{3}$ In the Northern Liberator O'Brien wrote: "At a moment like this, avoid disunion. [...] We cannot afford to lose a single man in our ranks." Even the Northern Star adopted a more charitable attitude for the new year. In the last edition before Christmas it had encouraged criticism of the BPU leadership. ${ }^{5}$ However, after the festival, a resolution from Rochdale attacking the BPU Council was considered "a little incautiously expressed" by the editor, ${ }^{6}$ and three weeks later the Star was urging all Chartists to unite in support of the Convention.

"Our strength is in our union, our power in our voice, and our success in our perseverance. For now more than four months we have had a perfect political hurricane, and the Radicals, as if their battle had been won, have been fighting among themselves. We now trust that the short interval till the meeting of all the Parliaments will be spent in sober reflection. If we do not meet in London on the 4th, without spleen and recollection of the past, far better we should not meet at all. For ourselves, we have got some crooked blows, and we have given some hard ones; but we do hereby forgive and forget the past, in the hope that, in future, our united energy may be directed to the good cause."'

1 Delegate to the Convention for Renfrewshire, Newcastle, Carlisle, Wigton, Alva and Tillicoultry.

2 A. Wilson, The Chartist Movemant in Scotland (Manchester, 1970), p. 65.

3 W. Lovett, op. cil., p. 165.

4. Alummer, op. cit., p. 92.

5 Northern Star, 22 December 1838.

- Ibid., 29 December 1838.

? Ibid., 19 January 1839. 
And so attention was directed to making the final arrangements for the sending of delegates to the Convention, and the collection of monies for the National Rent and signatures for the National Petition, to ensure the success of the body which it was hoped would provide badly needed leadership and organization for the movement.

On 10 January 1839 a committee of delegates met in Birmingham to make final arrangements for the opening of the Convention. It was decided to meet on 4 February at Brown's Hotel, Palace Yard, but already there were signs of what was going to become a characteristic of the Convention, lack of preparation, and when the date came round, it was discovered that the Hotel had been reserved by the anti-CornLaw League for their first conference. ${ }^{1}$ Hasty arrangements were made and the Convention finally met at the British Coffee House, Charing Cross, subsequently moving to the hall of the Honourable and Ancient Lumber Troop, Fleet Street. ${ }^{2}$ However, the delegates met in good spirits, and the Northern Star was able to report that "harmony, union, and good feeling $[\ldots]$ pervaded the whole body. [...] there is neither jealousy nor intrigue [...]. England, Scotland, and Wales have shaken hands". ${ }^{3}$

The primary aims of the Convention were to increase the number of signatures to the National Petition, watch over its presentation to parliament, obtain by all legal means the enactment of the Charter, and to create and extend "a public opinion in favour of the principles of the People's Charter". " However, once the Convention started business it had a succession of problems to contend with. There were political divisions, as delegates split into moral- and physical-force factions, and after a short while a steady stream of desertions as delegates became disillusioned, short of money, or simply anxious to be at home with their families and friends. Moreover, there were continuing difficulties caused by the procedure for electing delegates, which was haphazard in the extreme. The Chartists made a mockery of their principles of equal representation and secret voting, because the elections were determined by the acclamation of a huge crowd, and the allocation of seats in the Convention was purely arbitrary, bearing little relation to either the distribution of population or sympathy for Chartism. The results were glaring inconsistencies in the

1 R. F. Webb, op. cit., p. 23.

2 W. Lovett, op. cit., p. 166.

Northern Star, 9 February 1839.

W. Lovett, op. cit., pp. 150, 167. 
representation of many areas, with London the most obviously overrepresented, and frequent election controversies, as faction fought faction for the right to choose a delegate, in places as far apart as Dumphries, Birmingham, East Surrey, and Tower Hamlets. ${ }^{1}$ These difficulties are reasonably well documented in the existing literature, ${ }^{2}$ but the internal and external problems of poor organization and obstruction have not been so closely examined.

One of the first mistakes of the Convention was its failure to recognise the need for William Lovett, the Secretary, to have adequate clerical assistance. Lovett's duties as secretary included recording the minutes of the Convention, keeping delegates informed of the contents of the voluminous correspondence which flooded in from all parts of the country, and answering requests for information, advice, newspaper orders, petition sheets, speakers and missionaries. ${ }^{3}$ When one considers that most letters, minutes and other Convention documents had to be handwritten ${ }^{4}$ by one man, it is hardly surprising that one of the most effective brakes on the progress of the Chartist movement was what Alfred Plummer described as the "spectre of poor communication". ${ }^{5}$ The only assistance which Lovett appears to have had was from Matthew Crabtree, ${ }^{6}$ who was employed as Door-keeper and messenger to the Convention, and provided little, if any, help with the secretarial duties. In contrast to the anti-Corn-Law League ${ }^{7}$ the Convention attempted to promote a national political movement with little or no effective organization. The main requirements were for full-time staff to maximise the National Rent, the Convention's sole source of income, the organization of speaker meetings for a concerted programme throughout the country, and, according to Lovett, an attempt to prevent the wastage of money which occurred when militant Chartists purchased muskets and pikes instead of contributing

1 Cf. British Museum, Additional Manuscripts (hereafter BMAM), 34245A, ff. 9, $13,17,23,34,284-85,331$.

${ }^{2}$ Cf. M. Hovell, op. cit., ch. VII passim; A. Wilson, op. cit., ch. V passim; R. G. Gammage, op. cit., ch. VI passim; and F. E. Rosenblatt, The Chartist Movement (London, 1967), ch. X passim.

3 See the letter-books of the Convention preserved in BMAM 34245A-B.

4 Some documents, such as the questionnaire sent out to Chartist associations early in the life of the Convention, were printed. BMAM 34245B, ff. 276-311. For an analysis of the results see D. J. Rowe, "The Chartist Convention and the Regions", in: Economic History Review, Second Series, XXII (1969).

- A. Plummer, op. cit., p. 97.

- BMAM 34245A, f. 28. The chief problem for the Convention was whether to allow him one or two weeks notice of termination of employment!

${ }^{7}$ Cf. N. McCord, The Anti-Corn Law League 1838-46, 2nd ed. (London, 1968), ch. VII passim. For a detailed comparison of the early years refer to the letterbooks of the League for 1838-40 in Manchester Central Reference Library. 
to the rent to finance "sending out delegates among the people". ${ }^{1}$ These things were not done, and inefficient national organization and unco-ordinated local activities were the inevitable consequences.

The letter-books of the convention contain numerous complaints from the provinces, which can be summarised as follows:

1) Failure to acknowledge receipt of rent and signatures;

2) Letters were not answered;

3) Failure to send important documents such as the Manifesto or list of ulterior measures;

4) Shortage of missionaries;

5) Failure to inform public meeting organisers whether Convention delegates would be available, who they might be or when they might arrive.

From Leamington Spa came the complaint that "our town contains twelve thousand inhabitants: - but, hitherto, we have not had a public meeting, in consequence of your inability to send us a delegate! [...] I may also remark that hundreds of individuals in this town are waiting an opportunity (which they have not yet enjoyed) of signing a 'petition' for 'universal suffrage' - 'vote by ballot' - and the other several propositions embodied in the People's 'Charter'." 2 The Northern Star replied to a query from Chester in its "Readers and Correspondence" column, with the statement that "we really are not able to say why an agitating visitor has not been sent to this city. We only know that similar enquiries reach us from all parts of the country." 3 In London, where there was a particular need for intensive organization in order that the capital could play the role of Paris in promoting radical change, after initial attempts by the Convention to stimulate active support enthusiasm waned, and gradually the Convention failed to provide either delegates for meetings or even petition sheets for some areas. ${ }^{4}$ Finally, from Tiverton, Devon, came a poignant reminder that Chartist activity continued to exist, even without the support of the Convention, in parts of the West Country:

\section{Sir}

I am directed by the members of the Working Mens Association of Tiverton in the county of Devonshire to inform you that the are sorry to tell you that the consider themselvs neglected by the

1 Northern Star, 29 December 1838.

2 BMAM 34245B, f. 38.

3 Northern Star, 18 August 1839.

${ }^{4}$ E.g., in Tower Hamlets and Southwark, BMAM 34245A, ff. 118, 275. Cited in

D.J. Rowe, "Failure of London Chartism", in: Historical Journal, XI (1968), pp. 477-78. 
Convention for the have niver sent them any information since the have met we have sent 4 soverigns and 2000 signatures to the Petition and we do consider that you ought to send us some information at times for to stimulate the people as well as send it all to the North we of Tiverton and other places in the West of England do feel ourselves neglected $[\ldots]$ we hope that you will not forget is for the future

Sir I Remain yours respectfully

Henry Hamlin Secretary ${ }^{1}$

Yet, not all of the associations which recognised the deficiencies of Convention organization wrote to complain. Some offered constructive ideas, like the Bloomsbury Chartist Association, which wrote to

"suggest to the Convention the propriety of adopting some better mode of organization than at present exists. [...] and they humbly hint at the following plan as likely to answer in some degree that End -

1st Dividing the whole country into districts and arranging that there shall be a Central Association in each District through whom as far as the law will allow Communications shall be addressed that may concern the various societies composing that District [...].

2 Appointing a number of committee men in each association who shall attend to the General Business of the Society".?

Unfortunately, such suggestions were not acted upon.

It was not that the Convention lacked active members. William Lovett devoted himself almost entirely to the Convention before his arrest at Birmingham in July 1839, and Bronterre O'Brien, during April 1839, spoke at nineteen public meetings and innumerable other smaller gatherings all in the space of nine days. ${ }^{3}$ The enigmatic Feargus O'Connor, likewise, devoted considerable time, energy and money in the pursuit of the Chartist millennium. At the beginning of 1839 he wrote: "From the 18th of December to the 15th of January, I have attended in London, Bristol, Manchester, Queenshead, Bradford, Leeds, Newcastle, Carlisle, Glasgow, Paisley, and Edinburgh, 22 large public meetings, and have travelled over 1500 miles". 4 Moreover, he frequently made himself ill through exhaustion. Henry

1 BMAM 34245B, f. 101.

2 Ibid., f. 57.

3 A. Plummer, op. cit., p. 105.

4 Northern Star, 19 January 1839. 
Vincent claimed that "I have spoke above two hours a day for thirteen months, and travelled six thousand and seventy-one miles". ${ }^{1}$ Nor did the Convention fail to recognise the need for missionaries and other activities. The committee for the Diffusion of Political Knowledge recommended the appointment of missionaries to visit Cornwall, Devon, Dorset, Kent and Hampshire, and later added Essex, Surrey, the West Midlands and East Anglia. The Convention clearly recognised the extent of the need for missionary activity, but not the problems inherent in such activity, or the effort needed to mobilize the resources required to do the job effectively. One problem was that missionaries were expected to cover too much ground. Two of the delegates, John Deegan $^{2}$ and William Gill, ${ }^{3}$ were briefed to "agitate" the people in Essex, Cambridge, Suffolk, Norfolk and Lincoln. ${ }^{4}$ Moreover, the missionaries' reports to the Convention give some indication of the more general problems encountered, as the following extracts illustrate:

Penzance March 22nd '39

Gentlemen,

Since we last wrote we have succeeded in rousing the people beyond our expectations altho we have not been able to hold meetings so rapidly as at first, our difficulties have been many every oppress and underhand annoyance has been resorted to by the Whigs \& Tories, and from the Authorities, in fact it appears to us that the Mayors in Cornwall have nothing to do but look after the Bellmen, The People have never heard politics nor had any agitation on that question [...] Thus you will see that we are obliged to go over the places twice [...] On Monday the 18th we held a meeting in the open air at Falmouth when an immense number of people attended, every manuevre was resorted to by the enemy to annoy us, one Whig gave the boys $5 /$ - worth of fireworks, it would not do, the people felt we and them had a common interest $[\ldots]$ Thus far have we gone every meeting has adopted the petition unanimously the spirit is raised in the people, but they want leaders to organise them, deputations are coming urging us to visit them but every night is arranged for, the middle class and the priests are moving Heaven and Earth against, the Teetotallers and the Methodists have monopolised the speakers and their leaders are against $\mathbf{u s}^{5}$

1 Western Vindicator, 6 April 1839.

2 Delegate to the Convention for Hyde, Stalybridge, Glossop and Newmills.

${ }^{3}$ Delegate to the Convention for Sheffield and Rotherham.

4 Norfolk Chronicle and Norwich Gazette, 16 March 1839.

5 BMAM 34245A, f. 148. 
However, despite these and other problems, the major difficulty for the missionaries was the inconsistent behaviour of the Convention. First, it appointed missionaries to undertake specific tasks, and then at the instigation of $\mathrm{O}^{\prime}$ Connor either refused to vote them sufficient money to continue their work, or demanded their immediate return to London, at a time when many associations were writing that "it will be almost impossible to collect anymore National Rent without some agitation by some stranger to the town". ${ }^{1}$ Robert Lowery ${ }^{2}$ strongly complained about being given one month to do a job, when "in fact 2 months would be too little to agitate this County", 3 making arrangements for meetings, and then being instructed to return to the Convention before the alloted period had expired. Other missionaries expressed their displeasure at being misrepresented in the Chartist press as absent from the Convention, and John Richards ${ }^{4}$ wrote: "I have no sinecure here but work work walk walk allmost day and night, by the report of the Convention I find that I am reported as a defaulter in not attending the sittings of the Convention, this I think rather unkind, for you cannot but know that I am as much Employed on the business of Convention as if I was in London, and I think I ought to be reported as on the business of the Convention." 5

Clearly, the Convention did not rise to meet the demands made of it. The failure to provide positive leadership destroyed much initial enthusiasm, and reduced the operational efficiency of the movement. If the Convention had given a lead it seems plausible to suggest that both the numbers of signatures appended to the National Petition, and contributions to the National Rent would have substantially increased. Admittedly the Petition collected the respectable total of $1,280,000$ signatures, but the financial position of the movement was never very healthy. Despite the various fund-raising methods employed in some communities sufficient money was never forthcoming.

The National Rent, which had its Chartist origins, like the Petition and Convention, in Birmingham, ${ }^{6}$ was the primary source of income for the early Chartist movement. Unfortunately the total sum collected, about $£ 1700,7$ was considerably below the $£ 10,000$ thought

1 Ibid., f. 235.

2 Delegate to the Convention for Newcastle and Northumberland.

3 BMAM 34245A, f. 169.

4 Delegate to the Convention for the Potteries.

S BMAM 34245A, f. 173.

- Although Attwood and the BPU would have copied the idea from O'Connell's Irish agitation.

7 J. T. Ward, Chartism (London, 1973), p. 114. 
necessary by Thomas Attwood. ${ }^{1}$ To put this sum into perspective it should be noted that profits accruing to O'Connor from sales of the Northern Star amounted to $£ 13,000$ in 1839. Radical money was available, working people in fact provided O'Connor's working capital, ${ }^{2}$ but it was directed into the wrong hands. The Rent which was collected barely sufficed to meet the minimum necessary expenses of the Convention, allowing little for missionary work or advertising, although some newspaper advertisements were paid for locally, and was considerably short of being sufficient to meet the legal costs of defending individual Chartists when Government repression was mounted on a massive scale in the second half of $1839 . .^{3}$ Yet, as the Birmingham Journal, edited by R. K. Douglas," remarked, "to the responsibility, weight, influence, and existence of the Convention [...] the national rent is essential". ${ }^{5}$

Even Rent administration was tainted with controversy. P. H. Munt $^{6}$ and R. K. Douglas were responsible for the collection and safety of the Rent prior to the convening of the Convention, but they do not appear to have been very business-like, as William Lovett was unable to get proper accounts from them at a later date. ${ }^{7}$ Moreover, a hostile Birmingham newspaper claimed that almost the whole of the local collection for the Rent of $£ 192$ had been squandered on personal expenses. ${ }^{8}$ Such accusations damaged the Convention throughout its existence. There were numerous reports that the financial department of the Convention was in "complete confusion", that various subscriptions were not acknowledged, and that others were not acknowledged or accounted for in full. ${ }^{9}$ A further scandal was propagated by

${ }^{1}$ K. E. Richardson, "Life and Times of Thomas Attwood" (unpublished Ph.D. thesis, Nottingham, 1965), pp. 444-45.

2 D. Read, Press and People 1790-1850 (London, 1961), pp. 98-99.

3 Although $£ 429$ was transferred to the Defence Fund on the dissolution of the Convention, this is further evidence of the inefficient manner in which it handled its financial affairs. Clearly inadequate to pay legal costs such a sum might have been crucial earlier in the year if it had been spent on strengthening the organization.

4 The owner and editor of the Birmingham Journal, and also delegate to the Convention for Birmingham.

- Quoted in the Morning Post, 7 February 1839.

- Delegate to the Convention for Birmingham.

7 BMAM 34245A, f. 272.

8 Morning Post, 8 February 1839.

- Cf. Morning Post, 16 April 1839. "Yesterday, Mr. Rogers, purse-holder for the Convention, said the Morning Post had traduced their character by stating that their financial department was in a state of great derangement. [...] He could tell the editor of that paper that it would be well for the Chancellor of the Exchequer if he could keep his accounts in the manner in which he $[. .$.$] kept the$ accounts of the Convention, and if his finances were in as prosperous a con- 
The Times after the Birmingham delegates had resigned from the Convention: "The Birmingham delegates have, we believe, all returned home; and one or two of them, in new cloaks, and otherwise attired in spic-span suits of the most modern London cut, appear to have profited, at least as far as the outward man is concerned, by their trip to the metropolis." 1 Whatever the validity of such reports, in the absence of convincing denials from the Convention, and an improvement in, at least, the efficiency of the Treasurer, there can be little doubt that they had an adverse effect on efforts to increase the movement's income.

Shortage of money also meant that the Convention could not enforce another one of the principles it was fighting for, namely, equal payment for all the representatives of the people, ${ }^{2}$ and caused conflict amongst the delegates, many of whom believed that they should be directly supported from the National Rent. It was, in fact, left to the discretion of individual constituencies to determine what proportion of their collections, assuming there were some, should go to their delegates and what to the National Rent. However, this was decided after many areas had made their contributions, and at least one delegate "thought that some misunderstanding existed in the provinces upon this point. His constituents were very poor though industrious men. He was afraid that they would not be able to make a second subscription, which they would have to enter upon if the money already contributed by them were devoted solely to general purposes." 3

Not all delegates were as fortunate as Peter Bussey, the delegate from Bradford, Yorkshire. He had an agreement with his constituents, which served to supplement his income, to send regular reports from the Convention. Thomas Frost said Bussey sent messages to be read in his beer-house, which was "like a theatre; there was a rush for early places, and all paid for admission". ${ }^{4}$ On the other hand, delegates

dition. [...] To their great dismay at a subsequent period of the day, the following facts were announced; - Mr. Cardo said that money had been forwarded from Devonshire and not acknowledged. Mr. Marsden said he had handed in $£ 5$ and only $£ 4$ had been acknowledged. Mr. Pitkeithley said of $£ 6$ national rent forwarded through him only $£ 4$ had been accounted for." See also the Examiner, 14 April 1839.

1 The Times, 11 March 1839.

${ }^{2}$ J. T. Ward, op. cit., p. 114, writes that "in the matter of members' payment, the Convention appears to have more closely followed Chartist prescript than in such matters as the secret vote or equal electoral districts". However, the evidence presented here suggests that any improvement was very limited.

${ }^{3}$ Northern Star, 9 February 1839.

4 Cited in A. J. Peacock, Bradford Chartism 1838-1840 [Borthwick Papers, 36] (York, 1969), p. 20, note 136. 
such as George Loveless, ${ }^{1}$ leader of the Tolpuddle Martyrs, found it impossible to attend more than a few meetings without financial assistance from the Convention, and implied as much in a letter to William Lovett explaining his position:

"I hereby acknowledge the reciept of your letter containing the following Resolution 'That the Secretary be requested to write to those Delegates who are absent without leave to know the reason of such absence' My reason and my only reason is the following I find it utterly impossible under present circumstances to leave home if I did I must hire a man to supply my place which at present I cannot afford to do. My Best Respects to the Convention wishing them all prosperity."2

Even George Julian Harney, one of the most popular young Chartist leaders, had difficulty in raising funds from Norwich, one of his constituencies. One of the local papers reported:

'In reference to the Norwich contributions to the 'National Rent', great complaints are made: $£ 7$ it seems, is all that has been sent; barely enough to pay Mr. Harney for three weeks and three days in London, at $£ 2$ per week, the weekly pay of the delegates: not much more than enough to pay his coach-hire. The call upon the people was most pressing, but was not responded to; and $\mathrm{Mr}$. Harney must either retire from the representation, or give his important services gratis."3

The unhealthy state of Convention finances precluded any possible attempts at ambitious organization building, but if one now turns to consider the wide disparities in the efficiency of provincial associations it reinforces the belief that some improvement was vitally necessary if the Convention was to realise its potential as the leader and mouthpiece of the working classes.

\section{III}

Some local Chartist associations were quite well organized, attracting a large degree of support from their local populations. Others were less efficient. But in both the extreme and intermediate cases problems

1 Delegate to the Convention for Dorset.

2 BMAM 34245A, f. 240. Loveless had only recently, August 1838, been installed in a new farm in Essex, paid for by radical subscriptions to the Dorchester Labourers' Farm Tribute, and was struggling to make a success of it. Cf. J. Marlow, The Tolpuddle Martyrs (London, 1971), pp. 214, 217.

${ }^{3}$ Norfolk Chronicle and Norwich Gazette, 30 March 1839. 
were created by external pressures and by lack of leadership from the Convention.

In most areas of political or socio-economic discontent it was relatively easy to create a formal Chartist organization either as a consequence of earlier radical agitation, or after Chartist sympathisers had read a propaganda address, such as those sent out by the LWMA, in their local newspaper, ${ }^{1}$ or, occasionally, after a visit by a Chartist missionary. ${ }^{2}$

In Leicester an open meeting was convened and the Leicester and Leicestershire Political Union formed. Members were expected to pay a subscription of $\frac{1}{2} \mathrm{~d}$ per week, and the union was "to consist of all persons of good moral character [who desired] to promote the cause of good and cheap government in every department of the state [...] recognising the only legitimate end of civil government to be the happiness and welfare of all, without distinction of party, sect, or station". ${ }^{3}$ The Leicester Union was reasonably successful, it formed a democratic structure and attracted large-scale support. To some extent it could manage without leadership from the Convention.

The same applied to only a minority of other associations, the best example being Bradford in the West Riding of Yorkshire. In the Bradford area the organization was quite remarkable. Each village in the area sent a delegate to meetings of the Bradford Northern Union, then occasionally representatives from these meetings would attend West Riding delegate meetings. There was a hierarchical structure with clearly defined responsibilities for each official. For example, there was a treasurer for the National Rent Fund, another for the Joseph Rayner Stephens Defence Fund, and another for general expenses. Moreover, organizational efficiency made it possible to pay collectors of signatures to the National Petition. ${ }^{4}$

Unfortunately, in many areas it proved difficult either to form Chartist associations, or, having formed them to sustain them, or to retain the active support of some areas because of the allegedly irresponsible behaviour of members of the Convention. In April 1839 The Times reported:

"NATIONAL CONVENTION. - Letters have been received by Lovett, the secretary, from Worcester, Dunfermline and Stirling, announcing that the working classes in those places repudiate the principles of the revolutionists. The letter from Worcester states

${ }^{1}$ Leicestershire Mercury, 3 November 1838.

${ }^{2}$ Cf. J. T. Ward, op. cit., pp. 96-100.

${ }^{3}$ Leicestershire Mercury, 5 January 1839.

4 A. J. Peacock, op. cit., p. 18. 
that it is impossible to collect the rent there. That from Dunfermline states that treason must be in the camp, and that if the Destructives and Levellers assembled in Bolt-court recommend physical force, they need not reckon on the working man of that town. The letter from Stirling announces that the working classes will seek their rights solely through constitutional means. A communication has also been received from Salisbury, stating that every means have been tried in vain to form the working men of that place into an association in connexion with the convention. No landlord could be found to grant them a room, no printer to print the bills, nor a crier to announce a meeting; and that of 50 men who had declared themselves favourable to the charter principles, 44 had deserted them."

Despite attracting considerable support in some areas there were many crucial ones where Chartism failed to win support. ${ }^{2}$ Many of the twilight areas claimed that successful agitation was impossible unless new faces, in the form of missionaries from the Convention, were made available. The following letter from Abingdon, Berkshire, gives some indication of the requests which flooded in to the Convention:

Sir,

Disgusted at the conduct of the Corn Law Tories at Devizes, I am desired, to inform you, that forty of us (ever ready the rights of Mankind to defend) have enroll'd our names, to form an Association, in this town, for the purpose of rendering assistance to the Members, and Delegates, of the National Convention, we have been using our utmost endeavour, for this last six weeks to increase our Numbers, but we have not mett with the success we could wish, having a very indolent sort of people, to contend with, but it is the general opinion here, if a Delegate was to Visit this Town and Neighbourhood, and call a Public Meeting, that many signatures may be obtained to the National Petition, and no doubt, be the means of forming an Association, of great magnitude. ${ }^{3}$

Problems of local organization were made more acute with the increasing withdrawal from Chartist activity of trade unions during 1839. In 1838 trade unions had provided all kinds of support for the early Chartist movement, supplying stewards to organize mass meetings and bands and flags to boost morale. For example, the

1 The Times, 16 April 1839.

2 Chartist Studies, ed. by Asa Briggs (London, 1959), p. 3.

3 BMAM 34245A, f. 224, dated 9 April 1839. 
Leicester Political Union invited "those Trade or Benefit Societies who are willing to make an offer of their flags, or Musicians of their services" 1 to participate in the next radical meeting in the town, and at least two, the Glove Union and the Brush-Makers Union, ${ }^{2}$ did so. In many other areas the trade societies made a valuable contribution to early Chartist organization, but after the "torchlight" meetings of the winter of $1838,{ }^{3}$ and in view of the growing ascendancy of the physical-force wing of the Chartist movement, a large number of them deemed it expedient to withdraw, or at least present a low profile, ${ }^{4}$ so as not to endanger their somewhat precarious legal position after recent incidents such as the transportation of the Tolpuddle Martyrs in 1834, and the Glasgow Cotton Spinners in 1837. With the withdrawal of much trade-union support, for whatever reasons, the ability of local Chartist associations to pursue their stated aims suffered accordingly.

The main activity of local Chartism centred around the National Petition and National Rent. The collection of signatures was a relatively straightforward process. Usually a meeting would be held and the audience would be asked to sign the petition. Afterwards the petition sheets would be held at some public or semi-public place in a central position and the people would be invited to sign their names. Sometimes the sheets would be distributed around radical public houses or private homes. ${ }^{5}$

Where large-scale Chartist activity existed it was reasonably easy to add to the petition. The main problem was simply that of mobilising sufficient collectors with enough sheets for people to sign them. However, in less active areas, and there were far too many of them, it was difficult to organize meetings which people would attend, without the attraction of Convention personalities who, more often than not, were unavailable. ${ }^{6}$ The other major difficulty was caused by different forms of harassment. When Henry Vincent spoke at Devizes in March 1839 the meeting was attacked by 200-300 Tories, allegedly composed

1 Leicester Chronicle, 24 November 1838.

2 Leicestershire Mercury, 24 November 1838.

${ }^{3}$ Cf. R. G. Gammage, op. cit., pp. 94-97.

* Although this is generally correct, there remained a number of individual trade unionists who were active in Chartism. Moreover, I. J. Protheroe, "London Chartism and the Trades", in: Economic History Review, Second Series, XXIV (1971), has shown how important trades support was to the organization of London Chartism in the 1840's.

${ }^{5}$ Cf. Suffolk Chronicle, 18 August 1838.

- Although O'Connor said that "if they were to admit the claims of all, they should require 350 delegates to furnish the demand" (the Charter, 12 May 1839), the Convention could surely have provided greater assistance than it actually did. 
of lawyers clerks, parsons, and drunken farmers, one of whom offered thirty shillings to any man who would fire upon Vincent, all shouting such slogans as "Corn Laws for Ever", "Church and State", "No Dissenters", "No bloody Whigs and Radicals", "Three Cheers for the Queen", and "Down with Vincent". ${ }^{1}$ This counter-demonstration was very successful; Vincent barely escaped without serious injury, and this provided encouragement to anti-Chartist forces elsewhere, especially in agricultural areas. In some places the Anglican and Methodist churches campaigned against Chartism. There were complaints from Boston, Lincolnshire, that the Wesleyans were obstructing the collection of signatures to the National Petition. ${ }^{2}$ Similar complaints came from Bolton, Lancashire, and at Sandbach in Cheshire it was stated that two sheets of the National Petition had been burnt. ${ }^{3}$ Finally, it was reported from Cornwall, where one magistrate wrote to the Home Secretary: "I cannot close without adding my very sincere approbation of the conduct of the Wesleyans of the Parish on the occasion" of a Chartist meeting, ${ }^{4}$ that the clergy were "going to every cottage door and declaring to the women if their husbands signed the 'National Petition' they would subject themselves to the penalty of transformation". ${ }^{5}$

Despite these and other forms of harassment, however, the petition was relatively easy to organize, provided local enthusiasm and activity could be stimulated or rekindled. On the other hand, the National Rent was much more difficult to collect, even though in theory it should have been quite simple. In Ipswich

"Plans were made at a meeting held in Oct. 1838 to raise the National Rent. Each parish in the town (12 in all) was to be a district and for each parochial district two collectors were to be appointed. Besides collecting the Rent in his district, the collector was to be a member of a National Rent Committee. This Committee, which was composed of the 24 collectors, was to meet weekly to consider progress, and to take account of the monies collected."6

Yet despite the preparation, and the enthusiasm of individuals, the results were very poor. Six months after the creation of the Ipswich

1 The Times, 28 March 1839.

2 BMAM 34245A, f. 320.

${ }^{3}$ The Examiner, 5 May 1839.

4ited in D. Thompson, The Early Chartists (London, 1971), p. 189.

5 BMAM 34245A, f. 178.

- Cited in H. Fearn, "Chartism in Suffolk" (unpublished M.A. thesis, Sheffield, 1955). 
rent organization it was reported that only about $£ 1$ had been collected. ${ }^{1}$ There were other ways of collecting money for the National Rent, but none proved to be universally successful. Many Chartist associations held well-attended radical dinners, ${ }^{2}$ but whether they raised funds as well as morale is not certain. In Birmingham antiCorn-Law meetings were used to make collections for rent. At Loughborough local Chartists were charged 1d each to listen to John Skevington ${ }^{3}$ give a progress report on the movement. ${ }^{4}$ In Renfrew an attempt was made to obtain money by canvassing the community's respectable and wealthy element. ${ }^{5}$ The Chartists of Aberdeen held a "Grand Chartist Ball for the Benefit of the National Rent" in their local Temperance Hotel. ${ }^{6}$ In some of the more industrial areas efforts were made to organize weekly collections of rent from sympathisers within the factory. ${ }^{7}$ London experienced considerable difficulties in the collection of rent because mass involvement in Chartism was confined to isolated desperately poor sections of the community, ${ }^{8}$ and in Rotherhithe the best that could be done was to construct a "National Rent Box" to make collections at the door after meetings. ${ }^{9}$ However, at least one association, that at Colne, discovered a reasonably successful method of raising money:

"We have got short addresses printed, by way of circulars, and leave them at every house for a day or two, and then go round and take them up, and receive the donations; and we find this to be a very good introduction, and would recommend it to our countrymen for their adoption where the rent is yet to collect."10

It was not an easy task to raise money for the National Rent, and by failing to promote those few good ideas for raising money that did exist, like the Colne one, the Convention did nothing to relieve the pressures on local groups. The problems were exacerbated by the amount of press coverage given to financial inefficiency, fraud and failures to acknowledge rent, and by the disappearance of some local

1 Essex Mercury, 9 April 1839.

${ }^{2}$ Cf. Northern Star, 12 January 1839.

3 Delegate to the Convention for Loughborough and Derby.

4 Lincolnshire Chronicle, 17 May 1839.

5 Morning Post, 2 April 1839.

- Ibid., 3 April 1839.

7 BMAM 34245A, f. 86

8 Ibid., f. 118.

Ibid., f. 165.

10 Northern Star, 15 December 1838. A copy of the circular is printed in full in D. Thompson, op. cit., pp. 193-94. 
collectors with the funds. ${ }^{1}$ It was not that money was not available - defence funds for individual Chartists attracted considerable support - but that more and more individuals and associations gradually lost confidence in the Convention, and therefore financial contributions to the National Rent declined.

Another method of collecting money and political support, which illustrates the failure of the Convention to provide leadership for local Chartism, was the use of "exclusive dealing". This, "dealing exclusively with shopkeepers of one's own political persuasion or withdrawing custom from shopkeepers who had followed an opposed line at elections", was a common political practice during this period. ${ }^{2}$ It could have been a peaceful and potentially successful tool of Chartist agitation, but only if the Convention had given a lead, as it was urged to do, ${ }^{3}$ in indicating precisely what procedures to adopt when dealing exclusively. This the Convention failed to do, and what had been intended as a peaceful "ulterior measure" was transformed into something quite different. The Examiner reported that in Newcastle "delegates from the body calling itself the Northern Political Union have been going about collecting subscriptions to the national rent, and using intimidation to effect their purpose", and in Halifax a man "called at the Northgate Hotel $[\ldots]$ and demanded a sum of money in support of the Chartist agitation, giving the landlady to understand that it would be worse for them if they did not comply with his request". ${ }^{4}$ Naturally, such activity provoked a response from the authorities and in August 1839, Russell, the Home Secretary, advised magistrates "to proceed against persons guilty of such illegal practices, as for a misdemeanour". 5 Local magistrates quickly followed this instruction, and before the end of the month two Leeds Chartists were found guilty of extortion by threats, after seeking subscriptions to the National Rent while "dark hints about the recent riots and bloodshed at Birmingham were thrown out", on the evidence of thirteen shopkeepers and publicans. ${ }^{6}$

The efficiency of local Chartist organization varied enormously throughout the country due to a multiplicity of causes, but most associations could have become more efficient in the pursuit of their stated aims had the Convention provided leadership for the move-

${ }^{1}$ Cf. The Examiner, 5 May 1839.

2 N. Gash, Politics in the Age of Peel (New York, 1971), p. 175.

3 BMAM 34245A, f. 298.

- The Examiner, 28 July 1839. See D. Thompson, op. cit., p. 194-95, for details of exclusive dealing in Bradtord.

- The Examiner, 11 August 1839.

- J. F. C. Harrison, "Chartism in Leeds", in: Chartist Studies, op. cit., p. 78. 
ment. ${ }^{1}$ With the Convention abdicating from this crucial role, provincial Chartism was virtually left to flounder alone. This was distinctly harmful to the movement, because to have achieved any success required concerted action not half-hearted independent initiatives, and because it prevented an easy flow of vertical and horizontal communications. Inadequate national organization and leadership inevitably reduced the impact of local Chartist activity during this period.

\section{IV}

Despite the organizational problems, by May 1839 the Petition had accumulated $1,280,000$ signatures and was ready for presentation to the House of Commons. Thomas Attwood was prevailed upon to take charge of the petition, but a further calamity befell the Convention when he declared

"that he could not move for leave to bring in a bill for the establishment of what was denominated the People's Charter. In every other point $[\ldots]$ he most heartily agreed with them. His objection to the principle of the Charter was, that it went to interfere with the principle of the ancient rights of the elective franchise of England, in as much as it would give to Ireland one half of the whole representation, that country, under the proposed regulations, being to return 200 members; whilst England, Scotland and Wales would elect but 400."2

However, despite Attwood's intransigent opposition to the principle of equal electoral districts, ${ }^{3}$ which accounts for there being only five points in the National Petition, the Convention had little alternative other than to ask him to present the Petition, which he duly did.

While confusion reigned over Attwood's attitude to the Charter, the Convention, which had already decided to transfer to a more favourable radical environment than London, moved to Birmingham. At the same time it published a Manifesto, ${ }^{4}$ for consideration at the Whitsun "simultaneous meetings", listing those "ulterior measures" which

\footnotetext{
1 Some local associations were quite efficient in their promotion of coffee-shops, news-rooms, temperance meeting houses, house building, co-operative retail stores, and churches. Although this did not help the national Chartist movement, it serves to indicate the reservoir of local talent available to the Convention had it been able to utilize it.

2 The Times, 8 May 1839, and the Charter, 12 May 1839.

3 For further explanation of Attwood's motives see his article in the Birmingham Journal, July 1841. There is a copy in BMAM 27821, f. 321.

1 BMAM 27821, f. 330.
} 
were to be undertaken in the event of the Petition being rejected. After some delays, partly due to the Bedchamber Crisis, the Petition was formally laid before the Commons on 14 June, and one month later (12 July) was defeated by 235 votes to $46 .^{1}$ A few days previous to this the Birmingham Bull Ring Riots had taken place, and as a consequence, Lovett, secretary of the Convention, was arrested. The Convention then met on $15 \mathrm{July}$ in a state of considerable excitement, and, in response to these two events, decided to proceed with the Sacred Month - i.e. general strike - beginning on 12 August. ${ }^{2}$ A few days later R. J. Richardson ${ }^{3}$ was writing to the Convention to declare that

"The reports of the state of the country I am sorry to see have been greatly exagerated I feel myself bound to give you a correct report of the state of Brighton Chichester Portsmouth Southampton Isle of Wight Plymouth and Manchester In Brighton the Association is of course good, but the nature of the town is such that the leaders even Mr. Good would not recommend us to say a word about ulterior measures In Chichester only 2 Gentlemen could be found who had courage to get out a placard announcing our intention to address the people and yet Mr. Dean could say in the Convention that the people in these places were ready to adopt the Ulterior Measures! Delusion!"4

Only one day after Richardson had written, the Convention met to reconsider its decision, and determined to seek further advice from the localities. Within days letters began to pour in from all parts of the country urging the Convention not to proceed with the Sacred Month. The letter received from Leamington is an articulate example of the sentiments expressed in the majority of the letters.

Gentn,

I beg to inform you that the members of our society have taken into consideration the subject of the proposed cessation of work; and we are unanimously of opinion that the decree which you have issued - that the "Holiday" shall commence on the twelfth day of August next, is, in the actual state of the country most preposterous and absurd.

I travel extensively throughout the country; and the result of

1 The House actually divided on the motion that the petitioners be heard at the bar of the House.

2 The idea of a sacred month was assiduously canvassed by William Benbow, who published a pamphlet entitled A Grand National Holiday and Congress of the Productive Classes (1832).

2 A former delegate to the Convention for Manchester.

4 BMAM 34245B, f. 53, dated 21 July 1839. 
my enquiries is that in no single district are the people in readiness to obey the instructions of the Convention on this subject; and that of the other "ulterior measures" not one are they prepared to adopt - except, perhaps that of "Exclusive Dealing", as this implies little personal sacrifice, and as little of the exercise of moral courage. In several towns the leader of the Chartists is himself a publican - his own house, probably, offers the only accommodation which can be procured for the holding of meetings; and as it is the sale of excisable articles that his business chiefly consists, you cannot, in such towns, rely on a very rigid abstinence from, at least, the articles of beer, spirits, and tobacco. ${ }^{1}$

Of 20 Chartist associations in England and Wales which wrote to the Convention, 16 were against the Sacred Month, only 3 were in favour, and 1 was undecided. ${ }^{2}$ In Scotland only 5 out of 43 associations to make known their feelings were in favour. ${ }^{3}$ As rank-and-file opinion became more widely known, Chartist leaders changed their minds about the propriety of proceeding with the Sacred Month, and by so doing destroyed much of the remaining confidence in their own and the Convention's credibility. On 15 July O'Brien implied, at a meeting in his own constituency of Stockport, his support for the Sacred Month and said that he had recently been at sixty radical gatherings in Scotland and Cumberland where support for the strike had been unanimous, ${ }^{4}$ yet within a few days he was seeking to reverse the Sacred Month decision. The Northern Star came out firmly against the strike in a powerful article from $\mathrm{O}^{\prime}$ Connor and a long editorial. ${ }^{5}$ Feargus O'Connor claimed that he had never favored such extreme action as the Sacred Month, but James Taylor ${ }^{6}$ wrote from Rochdale that his constituents were very unhappy about the vacillating behaviour of leading members of the Convention with regard to the Sacred Month, and that 'Mr. O'Connor is getting a good share of the blame which is thrown upon the Convention in this matter, for his leading article in the Star of last Saturday on this subject. I am told that in 2 or 3 districts it was suggested to have the Star burnt."?

Moreover, O'Connor also claimed that Bussey and Pitkeithly, as well as himself, the only representatives of Yorkshire at the Con-

1 Ibid., f. 72, dated 31 July 1839.

${ }^{2}$ Letters in BMAM 34245B.

3 The Charter, 25 August 1839.

4 A. R. Schoyen, op. cit., pp. 78-79.

5 Northern Star, 3 August 1839. Both the article and the editorial are reprinted in D. Thompson, op. cit., pp. 196-205.

- Delegate to the Convention for Rochdale and Middleton.

' BMAM 34245B, f. 123, dated 8 August 1839. 
vention, were all opposed to the Sacred Month, but only three days after the publication of this statement, Bussey, in one of the three letters favouring the Sacred Month referred to above, was writing:

\section{Gent ${ }^{n}$}

I am commanded by the delegates representing the various towns in the West Riding of Yorkshire to forward to you the following resolution unanimously agreed to by them at Heckmondwicke yesterday

Resolved that the Representatives in the general convention assembled have in their late vacillating conduct with regard to the fixing of the day for the commencement of the sacred month done infinite injury to our noble cause and we most earnestly request them on the earliest opportunity to fix permanently a certain day for that purpose without swerving therefrom. ${ }^{1}$

And lest it be thought that these were not Bussey's own sentiments, he added a footnote: "O'Connor's letter in the Star of last week has done infinite mischief here." There can be little surprise at the confusion of rank-and-file Chartists in these circumstances. However, on 6 August the Convention made its final decision about the Sacred Month when it declared that Chartists might strike for two or three days and hold demonstrations on 12 August, ${ }^{2}$ but the Sacred Month itself was cancelled.

Any new efforts at organization by the Convention in these circumstances would have been doomed to failure, because by then it had forfeited almost all claim to any leadership over the movement. However, there was growing recognition in the regions, especially Scotland, of the need for a drastic reappraisal of Chartist strategy after the poor performances of recent months. There was a realisation that the Convention was indecisive, and although not directly challenging it, a number of Scottish Chartist associations began to consider regional organization. The riots in Birmingham and increasing Government repression revived the political temperature throughout the country, Scotland being no exception, and provided the ideal opportunity for action.

Glasgow decided to take the initiative and Thomas Gillespie, ${ }^{3}$ secretary of the Glasgow Universal Suffrage Association, sounded out all of the principal associations with a view to holding a Scottish Convention. This took place between the 14 and 16 August in Glasgow,

1 Ibid., f. 114, dated 6 August 1839.

${ }^{2}$ Cf. R. G. Gammage, op. cit., p. 155.

${ }^{3}$ He had previously been secretary to the defence committee for the Glasgow Cotton Spinners, and a journalist with the New Liberator. 
and 64 delegates attended, 10 more than were originally accredited to the National Convention and substantially more than ever attended. ${ }^{1}$ The reports given in from the 43 districts represented at the Convention calling for lecturers, missionaries, further agitation and generally better organization ${ }^{2}$ stand as an indictment of the performance of the National Convention. The Scottish delegates resolved: "From the report given in, we find $[\ldots]$ a uniform and strong expressed desire for extending and perfecting the present organization [...]. After mature deliberation, the Convention of Scottish delegates have agreed to a plan of organization, which we recommend to your careful dispassionate consideration." 3 The plan called for a cellular organizational structure in units of ten, with appointed collectors, a Central Committee for Scotland, an Executive Council of seven and a paid Secretary. ${ }^{4}$ Unlike their national colleagues the Scots wasted little time and quickly agreed to promote "efficient organizations at local, county and national levels, for the creation, mobilisation and direction of public opinion, was regarded as the vital key to the Charter". ${ }^{5}$ The success of the Scottish Convention provides a direct contrast to the failure of its national counterpart to provide effective leadership in the country as a whole.

During its early life the Convention inspired tremendous confidence, and Joseph Smith ${ }^{6}$ probably expressed the feelings of many Chartists when he wrote in March 1839:

"I trust that there is no intention of terminating the session of the Convention at the period of the prorogation of the Imperial Parliament. [...] Thousands of districts are yet uncanvassed; and the permanent sitting of a Board or Convention in London appears an indispensable condition almost of the very existence of Chartist Associations in the provinces."

Yet, within six months such confidence had almost totally evaporated, and the Convention was allowed to die unmourned, thus providing a useful measure of its failure. It was finally dissolved on 6 September

${ }^{1}$ Cf. the weekly tables of attendances at the Convention published in the Charter, e.g., 3, 10, 24 and 31 March 1839.

2 The Charter, 25 August 1839.

s Ibid., 1 September 1839.

4 Ibid.

S A. Wilson, op. cit., p. 87.

- Secretary of the Leamington Radical Association.

? BMAM 34245A, ff. 111-12. 
1839 in considerable acrimony and arrears of rent, ${ }^{1}$ and, indecisive to the last, unable to determine which of three draft valedictory addresses to publish. ${ }^{2}$

The early Chartist movement was clearly not an efficient instrument for mobilizing and sustaining support. Moreover, the legal prohibitions against radical organizations cannot be used to defend the Convention's lack of vigour and direction in prosecuting the Chartist cause. The Home Secretary, Lord John Russell, not only refused to resort to emergency laws himself, but was extremely reluctant to make use of those that had survived from the time of his predecessors. No use was made of the powers for limiting freedom of association given by the Unlawful Societies Act of 1799, or the Seditious Meetings Act of 1817. Finally, in June 1839 some of the statutory restrictions were actually relaxed. ${ }^{3}$ There were legal restrictions on organization, but as the Government chose not to enforce them, and both the Anti-Corn-Law League and Scottish Chartists, and later the National Charter Association, successfully ignored them, the National Convention can rightly be accused of unnecessary caution at a time when initiative was called for. The inadequate attempts of the Convention at organization and leadership have been fully illustrated, and it must bear a large portion of the responsibility for the failure of the early Chartist movement to achieve any tangible gains. Gammage wrote that "The paucity of signatures to the petition was a proof that much of the work of conversion was yet to be accomplished; and if they had met themselves steadily about that work, instead of seeking to force ulterior measures on a people as yet unprepared for their adoption, they would have produced fifty times as much good, without a tithe of the mischief which resulted from their policy" ; 4 this is a fair assessment.

The Scottish Convention and the formation of the National Charter Association $^{5}$ in 1840 , both testified to the need for better organization than that which the "General Convention of the Industrious Classes" had been able to provide. To what extent Chartism could have been more successful had it been better led and organized is within the realm of speculation, and it is not the purpose of this article to engage in a counter-factual analysis of Chartist might-have-beens, but one should note that the period in question was a crucial one for the future development of Chartism. As such, it was the time when the movement

1 The Examiner, 1 September 1839.

2 Cf. M. Hovell, op. cit., p. 173.

s Sir L. Radzinowicz, A History of English Criminal Law, IV (Cambridge, 1968), p. 247.

4. G. Gammage, op. cit., pp. 156-57.

- Northern Star, 1 August 1840 . See also D. Thompson, op. cit., pp. 287-93. 
had its widest political and socio-economic basis for support, and with better organization and a more realistic appraisal of the strengths and weaknesses of the movement by the Convention, much more could and should have been achieved. 